\title{
Potensi Limbah Media Jamur Konsumsi untuk Menekan Penyakit Layu Bakteri (Ralstonia solanacearum) pada Tanaman Kentang
}

\author{
Noor Istifadah ${ }^{1^{*}}$ dan P. Ricky D. Sianipar ${ }^{2}$ \\ ${ }^{1}$ Departemen Hama dan Penyakit Tumbuhan, Fakultas Pertanian, Universitas Padjadjaran \\ ${ }^{2}$ Alumnus PS Agroteknologi, Fakultas Pertanian, Universitas Padjadjaran \\ *Alamat korespondensi: nistifad@yahoo.com
}

\begin{abstract}
The Potential of Spent Mushroom Substrate to Control Bacterial Wilt Disease (Ralstonia solanacearum) in Potato
\end{abstract}

Bacterial wilt caused by Ralstonia solanacearum is one of important diseases in potato. One of ecofriendly-control measures is the use of organic matters including spent mushroom substrate. This paper discussed the study that examined the potential of spent substrates of oyster mushroom (Pleurotus sp.), shiitake (Lentinus edodes), Auricularia auricula and composted spent mushroom substrate to inhibit the growth of Ralstonia solanacearum in vitro and to suppress the disease incidence of bacterial wilt disease in potato. The results showed that spent substrate of shiitake mushroom slightly inhibited the growth of $R$. solanacearum in vitro with inhibition zone $1.5 \mathrm{~mm}$. The spent mushroom substrate applied in the growth medium and drenching its water extract every week significantly reduced the disease incidence of bacterial wilt disease, however the suppression level was only 26.1\%. The spent substrates of oyster mushroom (Pleurotus sp)., $A$. auricula and composted spent mushroom substrate did not suppress the disease incidence.

Keywords : Lentinus edodes, Pleurotus, Auricularia auricula, organic matters, spent mushroom water extract

\begin{abstract}
ABSTRAK
Layu bakteri yang disebabkan Ralstonia solanacearum merupakan salah satu penyakit penting pada pertanaman kentang. Salah satu cara pengendalian penyakit yang ramah lingkungan adalah dengan menggunakan bahan organik, termasuk limbah media jamur konsumsi. Artikel ini mendiskusikan penelitian yang mengkaji potensi limbah media tanam jamur tiram (Pleurotus sp.), jamur shiitake (Lentinus edodes), jamur kuping (Auricularia auricula) dan kompos limbah media jamur konsumsi untuk menghambat $R$. solanacearum in vitro serta menekan penyakit layu bakteri pada tanaman kentang. Hasil percobaan menunjukkan air rendaman limbah media jamur shiitake relatif menekan $R$. solanacearum secara in vitro dengan zona penghambatan $1,5 \mathrm{~mm}$. Limbah media jamur shiitake yang diaplikasikan pada medium tanam dan air rendamannya disiramkan ke tanaman kentang setiap minggu sekali dapat menurunkan persentase tanaman layu secara nyata dibandingkan dengan kontrol, namun tingkat penekanannya hanya sebesar 26,1\%. Limbah media jamur tiram (Pleurotus sp.), jamur kuping (A. auricula) serta kompos limbah media jamur tidak menghambat $R$. solanacearum secara in vitro dan tidak dapat menekan penyakit layu bakteri pada tanaman kentang.
\end{abstract}

Kata kunci : Lentinus edodes, Pleurotus, Auricularia auricula, bahan organik, air rendaman limbah jamur 


\section{PENDAHULUAN}

Penyakit layu bakteri yang disebabkan oleh Ralstonia solanacearum merupakan salah satu penyakit penting pada tanaman kentang. Gejala pada tanaman tanaman terinfeksi biasanya berupa kelayuan yang dimulai dari daun-daun pucuk yang kemudian akan berlanjut pada kelayuan seluruh daun (warna daun masih hijau) dan akhirnya tanaman akan mati. Apabila batang tanaman terinfeksi dipotong dan dimasukkan dalam air maka akan tampak massa bakteri yang keluar dari batang tersebut. Patogen dapat bertahan pada ubi kentang, gulma maupun dalam tanah (Semangun, 2004; Agrios, 2005).

Penyakit layu bakteri ini sulit untuk dikendalikan karena patogen mempunyai kisaran inang yang relatif luas dan dapat bertahan dalam tanah. Aplikasi bakterisida memang dapat menekan penyakit ini, namun aplikasi senyawa kimia sintetik ke dalam tanah sangat beresiko karena dapat mencemari lingkungan serta mematikan berbagai mikroorganisme menguntungkan dalam tanah. Oleh karena itu, perlu diterapkan cara pengendalian yang ramah lingkungan.

Salah satu cara pengendalian ramah lingkungan adalah pengendalian dengan menggunakan bahan organik. Selain berfungsi sebagai pupuk organik, bahan organik juga berpotensi untuk mengendalikan berbagai penyakit tanaman. Kemampuan bahan organik untuk pengendalian penyakit terbawa tanah telah banyak dilaporkan (direview dalam Bailey \& Lazarovits, 2003; Noble \& Conventry, 2005).

Bahan organik yang berpotensi untuk digunakan dalam pengendalian penyakit adalah bekas media tanam jamur konsumsi. Limbah jamur konsumsi ini biasanya kurang dimanfaatkan atau hanya digunakan sebagai campuran dalam pembuatan kompos, padahal sebenarnya limbah tersebut dapat dimanfaatkan untuk mengendalikan penyakit tanaman. Kemampuan bekas media jamur konsumsi untuk menekan penyakit tular tanah telah dilaporkan, misalnya untuk menekan penyakit Fusarium pada tomat (Borrero et al., 2005) busuk coklat pada kentang (El-Fallal \& Moussa, 2008) dan layu Fusarium pada kapri (Ahlawat et al., 2008) serta jumlah sista nematoda Heterodera spp. (Palizi et al., 2009). Seperti bahan organik secara umum, limbah media jamur konsumsi dapat diaplikasikan langsung atau dibuat air rendamannya.
Pada paper ini didiskusikan hasil penelitian mengenai potensi bekas media beberapa jamur konsumsi yaitu jamur Tiram (Pleurotus, sp.), jamur Shiitake (Lentinus edodes) dan jamur Kuping (Auricularia auriculata) serta air rendamannya untuk menghambat $R$. solanacearum in vitro dan menekan penyakit layu bakteri yang disebabkan $R$. solanacearum pada tanaman kentang.

\section{BAHAN DAN METODE}

\section{Pengujian secara in vitro}

Pengujian ditujukan untuk mengetahui apakah air rendaman limbah media jamur konsumsi dapat menghambat $R$. solanacearum secara in vitro dan apakah penghambatannya karena adanya senyawa yang bersifat toksik terhadap patogen atau karena aktivitas mikroba dalam limbah tersebut. Percobaan dilakukan dengan Rancangan Acak Lengkap, dengan perlakuan berupa air rendaman limbah jamur tiram, shiitake dan jamur kuping serta kompos limbah media tanam jamur baik steril maupun non steril. Setiap perlakuan terdiri dari tiga ulangan.

Air rendaman limbah media jamur dibuat dengan cara mencampurkan antara limbah dengan air dengan perbandingan 1:4 (v/v) kemudian diinkubasikan pada wadah tertutup selama 2 minggu (Scheuerell \& Mahaffee, 2002). Air rendaman disaring sebelum digunakan. Untuk pengujian secara in vitro, air rendaman steril diperoleh dengan cara sterilisasi dengan mikrofilter (ukuran pori $0,2 \mu \mathrm{m}$ ). Untuk mempermudah filtrasi, sebelumnya air rendaman tersebut disaring dengan kertas saring.

Pengujian kemampuan air rendaman untuk menghambat pertumbuhan bakteri patogen dilakukan dengan menggunakan metode filter paper. Nutrient agar hangat sebanyak $9 \mathrm{ml}$ sebelum dimasukkan ke dalam petridish diinokulasi dengan suspensi bakteri $R$. solanacearum $\left(10^{7} \mathrm{cfu} / \mathrm{ml}\right)$ sebanyak $1 \mathrm{ml}$. Potongan filter paper steril (diameter $1 \mathrm{~cm}$ ) dicelupkan ke dalam air rendaman limbah jamur sesuai perlakuan, kemudian diletakkan di atas media NA yang telah diinokulasi dengan patogen. Munculnya zona bening di sekitar filter paper diamati lebarnya setiap hari sampai 7 hari setelah inokulasi.

\section{Pengujian di rumah kaca}


Percobaan bertujuan untuk mengetahui kemampuan limbah media jamur konsumsi untuk menekan penyakit layu bakteri. Percobaan dilakukan dengan menggunakan Rancangan Acak Kelompok dengan perlakuan yaitu aplikasi limbah media tanam jamur Tiram, Shiitake dan Kuping dalam lubang tanam dan penyiraman dengan air rendamannya setiap minggu atau 2 minggu sekali. Setiap perlakuan terdiri dari 3 ulangan dan pada setiap ulangan terdapat 8 tanaman kentang.

Kentang yang digunakan adalah kentang varietas Granola. Untuk mempermudah inokulasi dan juga untuk mendapatkan tanaman yang relatif seragam, digunakan tanaman kentang yang telah berumur 10 hari. Bibit kentang ditanam pada kotak plastik berukuran $30 \times 50 \mathrm{~cm}$ yang berisi tanah yang telah dipasteurisasi (dikukus selama 4 jam). Dalam satu kotak ditanami 8 tanaman kentang. Sebelum tanam, perakaran kentang dilukai untuk mempermudah terjadinya infeksi. Limbah media tanam jamur (sesuai dengan perlakuan) diaplikasikan pada lubang tanam sebanyak $3 \mathrm{~g}$ per lubang tanam dan air rendamannya. Inokulasi $R$. solanacearum dilakukan dengan menyiramkan suspensi bakteri $\left(10^{7}\right.$ cfu per $\left.\mathrm{ml}\right)$ sebanyak 20 $\mathrm{ml} /$ lubang tanam. Penyiraman air rendaman limbah media tanam jamur konsumsi sebanyak 20 $\mathrm{ml} /$ lubang tanam, dilakukan setiap 1 atau 2 minggu sekali (sesuai perlakuan) sejak inokulasi $R$. solanacearum pada tanaman kentang.

Pengamatan awal kemunculan gejala layu (masa inkubasi) dilakukan setiap hari, sedangkan pengamatan persentase tanaman layu dilakukan setiap 3 hari sekali sampai tidak ada lagi penambahan tanaman yang layu (terutama pada perlakuan kontrol). Data persentase tanaman terinfeksi dianalisis secara statistik dengan menggunakan program SPSS 20. Perbedaan rata-rata antar perlakuan diuji dengan uji Tuckey HSD pada taraf $5 \%$.

\section{HASIL DAN PEMBAHASAN}

\section{Pengujian secara in vitro}

Pada pengujian secara in vitro, penghambatan terhadap pertumbuhan bakteri lebih didasarkan pada penghambatan melalui mekanisme antibiosis. Senyawa toksik yang ada dalam air rendaman diharapkan dapat terdifusi ke media dan menghambat pertumbuhan bakteri $R$. solanacearum sehingga menimbulkan zona bening atau zona penghambatan. Dari hasil pengujian secara in vitro diketahui bahwa diantara limbah media tanam jamur yang diuji, hanya perlakuan dengan air rendaman limbah shiitake yang menghasilkan zona penghambatan walaupun hanya sekitar $0,8-1,5 \mathrm{~mm}$ (Tabel 1). Jamur shiitake dilaporkan dapat menghasilkan senyawa yang dapat menghambat bakteri (Casarali et al., 2011). Limbah media shiitake kemungkinan masih mengandung metabolit sekunder dari shiitake sehingga limbah yang steril pun masih dapat menghasilkan zona hambat walaupun sangat kecil yaitu rata-rata $0,7 \mathrm{~mm}$.

Tabel 1. Kemampuan air rendaman limbah media jamur konsumsi untuk menekan R. solancearum secara in vitro.

\begin{tabular}{lc}
\hline \multicolumn{1}{c}{ Perlakuan } & $\begin{array}{c}\text { Rata-rata lebar zona bening } \\
(\mathbf{m m})\end{array}$ \\
\hline Air rendaman limbah jamur tiram steril & 0,0 \\
Air rendaman limbah jamur kuping steril & 0,0 \\
Air rendaman limbah jamur shiitake steril & 0,8 \\
Air rendaman limbah jamur kompos steril & 0,0 \\
Air rendaman limbah jamur tiram non steril & 0,0 \\
Air rendaman limbah jamur kuping non steril & 0,0 \\
Air rendaman limbah jamur shiitake non steril & 1,5 \\
Air rendaman kompos limbah jamur non steril & 0,7 \\
Kontrol & 0,0 \\
\hline
\end{tabular}

Dibandingkan dengan air rendaman limbah jamur shiitake yang steril, perlakuan dengan air rendaman limbah shiitake yang non steril menunjukkan zona penghambatan yang relatif lebih besar. Pada perlakuan kompos dari limbah jamur yang non steril juga menunjukkan zona hambat 
(walaupun kecil), sedangkan pada kompos limbah steril tidak menghasilkan zona hambat. Hal ini kemungkinan karena pada air rendaman non steril senyawa toksik tidak hanya dari metabolit sekunder jamur konsumsinya saja namun dapat pula dari metabolit sekunder mikroorganisme yang ada dalam air rendaman tersebut. Keberadaan mikroorganisme yang ada dalam air rendaman sangat berperan dalam penghambatan patogen oleh air rendaman bahan organik (EL-Masry et al., 2002; Borrero et al., 2005).

Pada penelitian ini, jamur tiram (Pleurotus sp.) tidak dapat menghambat $R$. solancearum. Pada penelitian lain, baik jamur Tiram maupun ekstrak air limbah media tanamnya dapat menghambat $R$. solanacearum dengan lebar zona hambat $(8-10 \mathrm{~mm})$ (El-Fallal \& Mousa, 2008). Perbedaan hasil tersebut kemungkinan terkait dengan perbedaan spesies dari jamur tiramnya dan juga bahan dasar dari medianya. Jamur yang digunakan pada penelitian ini adalah jamur tiram putih Pleurotus ostreatus dan media yang digunakan adalah serbuk gergaji dan dedak, sedangkan pada penelitian El-Fallal \& Mousa (2008) adalah Pleurotus columbianus, $P$. pulmonaris, dan $P$. floridanus serta media yang digunakan adalah berupa jerami gandum. Casaril et al. (2011) melaporkan bahwa isolat jamur dan komposisi medianya berpengaruh terhadap produksi metabolit sekundernya.

\section{Pengaruh Limbah media jamur konsumsi terhadap penyakit layu bakteri ( $R$. solanacearum) pada tanaman}

Pada penelitian ini, aplikasi limbah media jamur konsumsi yang diuji relatif dapat menghambat kemunculan gejala kelayuan pada tanaman kentang yang diinokulasi dengan bakteri $R$. solanacearum. Pada tanaman yang diberi perlakuan limbah jamur, kemunculan gejala kelayuan pada tanaman kentang terjadi pada 8-14 hari setelah inokulasi, sedangkan pada kontrol gejala mulai muncul 6 hari setelah inokulasi patogen. Limbah medium jamur yang telah dikomposkan tidak dapat menghambat kemunculan gejala (Tabel 2).

Tabel 2. Pengaruh limbah media tanam jamur konsumsi terhadap penyakit layu bakteri ( $R$. solanacearum) pada tanaman kentang.

\begin{tabular}{lccc}
\hline \multicolumn{1}{c}{ Perlakuan } & $\begin{array}{c}\text { Masa } \\
\text { inkubasi } \\
\text { (hari) }\end{array}$ & $\begin{array}{c}\text { Persentase } \\
\text { tanaman layu } \\
(\%)\end{array}$ & $\begin{array}{c}\text { Persentase } \\
\text { Penghambatan (\%) }\end{array}$ \\
\hline A. Limbah jamur tiram - setiap 7 hari & 10 & 83,3 bc & 13,0 \\
\hline B. Limbah jamur tiram - setiap 14 hari & 8 & 87,5 bc & 8,7 \\
\hline C. Limbah jamur shiitake- setiap 7 hari & 14 & $70,8 \mathrm{~b}$ & 26,1 \\
\hline D. Limbah jamur shiitake - setiap 14 hari & 10 & 83,3 bc & 13,0 \\
\hline E. Limbah jamur kuping - setiap 7 hari & 10 & 87,5 bc & 8,7 \\
\hline F. Limbah jamur kuping - setiap 14 hari & 14 & 87,5 bc & 8,7 \\
\hline G. Kompos limbah jamur - setiap 7 hari & 6 & 87,5 bc & 8,7 \\
\hline H. Kompos limbah jamur - setiap 14 hari & 6 & 83,3 bc & 13,0 \\
\hline I. Bakterisida (berbahan aktif oksitetrasiklin) \\
setiap 7 hari
\end{tabular}

Walaupun aplikasi limbah media jamur konsumsi dapat memperlambat kemunculan gejala, namun perlakuan tersebut kurang efektif dalam menekan persentase tanaman terinfeksi. Aplikasi limbah budidaya shiitake pada media tanam dan penyiraman dengan air rendamannya seminggu 
sekali dapat menekan persentase tanaman terinfeksi, namun tingkat penekanannya hanya sebesar $26,1 \%$. Pada perlakuan dengan limbah jamur tiram dan jamur kuping, persentase tanaman terinfeksi bahkan tidak berbeda nyata dengan kontrol. Begitu juga dengan perlakuan dengan limbah media jamur yang telah dikomposkan.

Kurang efektifnya limbah media tanam jamur konsumsi untuk menekan penyakit layu bakteri ( $R$. solanacearum) pada kentang, berbeda dengan hasil penelitian lain yang melaporkan kemampuan limbah jamur tiram (El-Fallal \& Moussa, 2008; Palizi et al., 2009) dan jamur shiitake (Inagaki et al., 2011) untuk menekan penyakit tanaman. Perbedaan hasil tersebut kemungkinan terkait dengan jenis species atau isolat serta komposisi media yang digunakan untuk budidaya jamurnya.

Pada penelitian ini, aplikasi bakterisida juga masih kurang efektif dalam menekan penyakit layu bakteri pada tanaman kentang. Aplikasi bakterisida berbahan aktif oksitetrasiklin seminggu sekali hanya dapat menekan persentase tanaman layu sebesar $43,5 \%$. Penyakit layu bakteri pada kentang memang penyakit yang sulit untuk dikendalikan. Oleh karena itu, pengendalian haruslah dilakukan secara terpadu dimana berbagai cara pengendalian yang kompatibel diintegrasikan sehingga dapat meningkatkan efek pengendalian yang dihasilkan.

\section{SIMPULAN DAN SARAN}

Berdasarkan hasil yang diperoleh dapat diambil simpulan bahwa : Air rendaman limbah media jamur shiitake (L. edodes) dapat menghambat $R$. solanacearum secara in vitro dengan zona penghambatan sebesar 1,5 mm. Limbah media jamur shiitake (yang diaplikasikan pada medium tanam dan air rendamannya disiramkan ke tanaman kentang setiap minggu sekali dapat menurunkan persentase tanaman layu secara nyata dibandingkan dengan kontrol, namun tingkat penekanannya hanya sebesar 26,1\%. Limbah media jamur tiram (Pleurotus sp.) dan jamur kuping (A. auricula) serta kompos limbah media jamur tidak dapat menekan penyakit layu bakteri pada tanaman kentang.

\section{UCAPAN TERIMAKASIH}

Penelitian ini merupakan bagian dari Penelitian Strategis Nasional, DP2M, DIKTI. Untuk itu, penulis mengucapkan terima kasih kepada DP2M DIKTI, Lembaga Penilitian dan Pengabdian pada Masyarakat (LPPM) yang telah memfasilitasi pelaksanaan penelitian ini. Terimakasih juga disampaikan kepada Perusahaan Jamur IP Farms, Lembang terutama Ibu Astrid Sunarti dan ibu Hesti, serta Bapak Athan di Garut yang telah membantu menyediakan bekas media tanam jamur konsumsi.

\section{DAFTAR PUSTAKA}

Agrios, GN. 2005. Plant Pathology. Fifth Edition. Academic Press. San Diego.

Ahlawat, OP, K Manikandan, MP Sagar, D Raj, P Gupta and B Vijay. 2011. Effect of composted button mushroom spent substrate on yield, quality and disease incidence of Pea (Pisum sativum). Mushroom Research 20 (2) : 87-94

Bailey, KL and G Lazarovits. 2003. Suppressing soilborne diseases with residue management and organic amendments. Soil \& Tillage Research 72 : 169-180

Borrero, C, MJ Infantes, E González and M Avilés. 2005. Relation between suppressiveness to tomato fusarium wilt and microbial populations different growth media. Pp. 425-430 in Proceeding Internasional Seminar on Soilless Culture and Hydroponics (Ed: M. U. Gavilán). Acta Hort. 697 ISHS.

El-Fallal, AA and Z Moussa. 2008. Prospects for biocontrol of brown rot disease of potato in vitro and under greenhouse conditions. Plant Pathology Journal, 7 (1):54-64

Inagaki, H, A Yamaguchi, K Kato, C Kageyama and $\mathrm{H}$ Iyozumi. 2011. Induction of systemic resistance to anthracnose in cucumber by natural components of Allium vegetables and shiitake mushrooms. Pp. 28-735 in Science against microbial pathogens: communicating current research and technological advances. A. Méndez-Vilas (Ed.), Formatex, Spain.

EL-Masry, MH, AI Khalil, MS Hassouna and HAH Ibrahim. 2002. In situ and in vitro suppressive effect of agricultural composts and their water extracts on some phytopathogenic fungi. World Journal of Microbiology \& Biotechnology 18: 551-55. 
Noble, R and E Conventry. 2005. Suppression of soil borne plant disease with compost: a review. Biocontrol Science and Technology, 15:3-20

Palizi, P, EM Goltapeh, E Pourjam, N Safaie. 2009. Potential of oyster mushrooms for the biocontrol of Sugar Beet Nematode (Heterodera Schachtii). Journal Of Plant Protection Research, 49, (1) :27-33.
Scheuerell, S and W Mahaffee. 2002. Compost tea: principles and prospects for plant disease control. Compost Science and Utilization, 10: $313-338$

Semangun, H. 2004. Penyakit-penyakit Tanaman Hortikultura di Indonesia. Gajah Mada University Press. Yogyakarta. 